\title{
A DESCRIPTION OF THE STUDENT'S PROBLEM SOLVING SKILLS BASED ON PERSONALITY TENDENCY
}

\author{
Rina Oktaviyanthi'), Yani Supriyani' ${ }^{2)}$ \\ 1)Universitas Serang Raya, rinaokta1210@yahoo.com \\ 2)Universitas Serang Raya, yanisupriani92@yahoo.com
}

\begin{abstract}
Educational psychology theory assumed that personality is an integration of the whole traits, abilities, and motivations of the individual, including temperament, attitudes, opinions, beliefs, emotional responses, character, and morals. Personality tendencies are non-cognitive characteristics possessed by each individual, in this case is student. Knowing and understanding the personality characteristics of the students is a step that needs to be done by teacher because each student has a different way and respond to access information. This study focuses on the tendency of the student's personality and its implications on mathematical problem solving skills. The purpose of the study is to describe how students with individual personality tendencies do mathematical problem solving. By knowing overview of positive attitudes on each personality tendencies associated with mathematical problem solving skills, the teacher as the facilitator will get references to any forces that appear on each personality tendencies and may be used as consideration in designing learning mathematics. Subjects in this study were students aged 15-18 years (student of class XI) Manyar SMAN 1 Gresik, East Java. The approach used in this study is a qualitative approach with descriptive exploratory method. The instruments used to collect data are tests and questionnaire research. For additional guidance interviews are used as well. The results of the study showed that of the four personality tendencies studied, students tended Melancholy personality fulfilled all indicators mathematical problem solving skills.
\end{abstract}

Key words: non-cognitive characteristics, personality, problem solving

\section{INTRODUCTION}

Problem solving skills have always been important in many professions. Problem solving is recognized as an important life skill involving a range of processes including analyzing, interpreting, reasoning, predicting, evaluating and reflecting (Anderson, 2009). It is a fundamental component of the school mathematics curriculum in many countries, including Indonesia. Giganti (2007) stated that there are three parts to learning mathematics: skills, concepts and problem solving. He declared that 
problem solving is important skills in the classroom because it requires the students to combine skills and concepts in order to deal with specific mathematical situations (problems).

Problem solving is an integral part of the learning mathematics. Become skilled at solving the problems can facilitate the students in everyday life and the world of work that was involved. Instructional programs from prekindergarten through grade 12 should enable all students to: (1) build new mathematical knowledge through problem solving; (b) solve problems that arise inmathematics and in other contexts; (3) apply and adapt a variety of appropriate strategies to solve problems; and (d) monitor and reflect on the process of mathematical problem solving (NCTM, 2000). The general indicators of problem solving in this study refers to the exposure PCS (2005), these are as follows:

Table1. Research Indicators of Problem Solving

\begin{tabular}{|c|c|}
\hline General Indicators & Technical Indicators \\
\hline \multirow{3}{*}{ 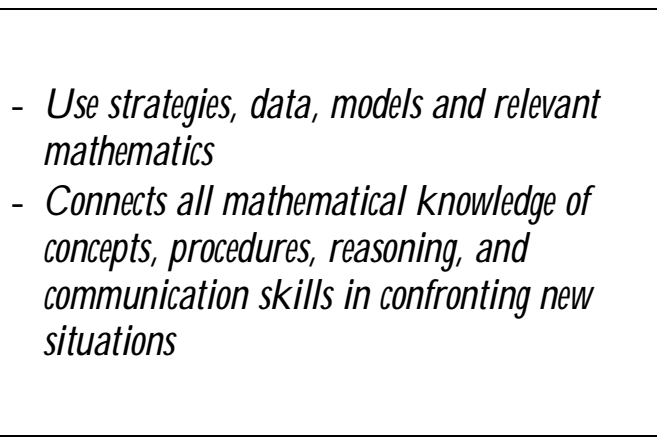 } & $\begin{array}{l}\text { Identifying information which has been known, } \\
\text { asked, and sufficient information that to be needed } \\
\text { using student's own words }\end{array}$ \\
\hline & $\begin{array}{l}\text { Formulating a mathematical problem or arranging a } \\
\text { mathematical model of the problem based on } \\
\text { student's understanding of the problem }\end{array}$ \\
\hline & $\begin{array}{l}\text { Illustrating the relationship of the problem with } \\
\text { some of concepts which is needed to solve the } \\
\text { problem }\end{array}$ \\
\hline \multirow{2}{*}{$\begin{array}{l}\text { Reoogizeandformilateprddens } \\
\text { - Useressoning(spatial, inductive, statistical, } \\
\text { or proportional) in newsettings }\end{array}$} & $\begin{array}{l}\text { Determining proper strategy that to be applied in } \\
\text { resolving the problem based on previously } \\
\text { information }\end{array}$ \\
\hline & Arranging the plan of problem solving \\
\hline \multirow{2}{*}{$\begin{array}{l}\text { - Judgethereasconableness and comethess of } \\
\text { sdutions } \\
\text { - Generate, extendand modify procetures }\end{array}$} & $\begin{array}{l}\text { Solving the problem with the problem solving } \\
\text { method }\end{array}$ \\
\hline & $\begin{array}{l}\text { Verifying whether any such the problem solving } \\
\text { method is true or can be proven } \\
\text { Providina a different wav of solvino a problem }\end{array}$ \\
\hline \multirow{3}{*}{$\begin{array}{l}\text { Useacamilated knowkedge of mathematics in } \\
\text { newsituations }\end{array}$} & $\begin{array}{l}\text { Providing a different way of solving a problem } \\
\text { Looking back to the things student has done, include } \\
\text { testing for solving the problem which is answered by } \\
\text { student }\end{array}$ \\
\hline & $\begin{array}{l}\text { Explaining/ interpreting the results as the original } \\
\text { problem }\end{array}$ \\
\hline & $\begin{array}{l}\text { Giving the meaning of the solved problem that has } \\
\text { gained }\end{array}$ \\
\hline
\end{tabular}

To create learning that facilitates the appearance of the processes that lead to the problem solving skills of students is certainly not an easy thing. Beside the material content, teacher as facilitator would consider a lot of things. Below mentioned by HM Inspectorate of Education (2010) the things that need to be considered by teacher on how to construct and encourage students to achieve problem solving skill process:

1. provide learning realistic environments rich in number and mathematical contexts, well-planned interdisciplinary projects which extend mathematical skills and allow their application in new contexts, reflecting that the school community values mathematics and recognizes that mathematical skills and, importantly, understanding are key to being a successful learner;

2. use more relevant and exciting contexts to engage and enthuse learners, including a variety of 
questioning techniques to probe learners' understanding, enabling them to communicate mathematical ideas and develop higher-order thinking skills, including reasoning;

3. involve whole learners' activities with their uniqueness characteristics;

4. use of formative assessment to help young people identify next steps and improve their learning.

The third above is the focus of research that engaging the unique characteristics of students in learning activities. Knowing and understanding the characteristics of the students is a step that needs to be done by each teacher because each student has individual differences in access and respond information. In Today's Mathematics Student, Latterell (2007) stated that understand the characteristics of the students both in terms of motivation, interest, personality, the way students process information, and other unique properties on the student becomes a fairly important part to gain effectiveness in teaching. Characteristic of students by Uno (2007) can be regarded as the personal characteristics of the students. Student characteristics are aspects or qualities of individual students consisting of personality tendency (including interests, attitudes, and motivations), learning styles, abilities of thinking, and the previous ability. So that the characteristics of each individual, in this case students, is unique.

Engaging the unique characteristics of students in learning as one of the elements that need to be concerned is not only to build problem solving skills but to encourage mathematics achievement of students. By knowing the uniqueness of students the teacher will increasingly realize that there are psychic aspects on students that need to be compensated and given attention. Regarding to the characteristics of students in aspects of personality tendencies, Handayani (in Oktaviyanthi, 2007) stated that students who understand his personality will have a positive impact on every aspect of life such as academic, achievement, personal development, the distribution of talents and interests. It happens because the students notice themselves primarily understand the personality, so that it can support the students in learning process.

One of the tendencies in the study of patterns of personality psychology is the tendency found by Hippocrates in 370 BC (Chapman, 2009). Hippocrates divided personality types based on the balance of fluids in the body of an individual, namely Blood, Black Bile, Yellow Bile, and Phlegm. In the 190 AD, Galenus enhanced the personality of the division of Hippocrates into Sanguine (Blood), Melancholic (Black Bile), Choleric (Yellow Bile) and Phlegmatic (Phlegm). The trend of HippocratesGalenus personality tendencies better known as four of personality temperaments is most acceptable throughout the development of the human personality psychology because it was based on the biological aspects of the individual.

Based on the above explanation, the authors are interested to study and describe how the problem solving skills of student in terms of the tendency of personality types. By having a description of positive attitudes in students respective patterns of personality tendencies associated with problem solving, teachers can get a reference which student's forces that appear on each aspects of personality tendencies associated with problem solving. Further references can be used as a consideration not only in designing meaningful learning mathematics, but also to decide the right actions and determine the appropriate treatment in order to improve student's problem solving skills. 
Table2 Research Indicators of Hippocrates-Galenus Personality Tendencies

\begin{tabular}{|c|c|c|c|c|}
\hline \multirow{2}{*}{$\begin{array}{l}\text { Personality } \\
\text { Aspects }\end{array}$} & \multicolumn{4}{|c|}{ Personality Tendencies } \\
\hline & Sanguine & Melancholic & Phlegmatic & Cholenic \\
\hline Characters & $\begin{array}{l}\text { - Animated } \\
\text { - Convining } \\
\text { - Fumy } \\
\text { - Talker } \\
\text { - Brassy } \\
\text { - Intemupts } \\
\text { - Talk adive }\end{array}$ & $\begin{array}{l}\text { - Analytical } \\
\text { - Pesistert } \\
\text { - Plarner } \\
\text { - Idaglistic } \\
\text { - Inseare } \\
\text { - Suspicias } \\
\text { - Critical }\end{array}$ & $\begin{array}{l}\text { - Reserved } \\
\text { - Obliging } \\
\text { - Reticent } \\
\text { - Fearfil } \\
\text { - Womier } \\
\text { - Daibtfil } \\
\text { - Indifferent }\end{array}$ & \begin{tabular}{|l} 
- Adkethrraus \\
- Compditive \\
- Sure \\
- Tenaiaus \\
- Chif \\
- Manipulative \\
- Strongrvilled
\end{tabular} \\
\hline Temperaments & $\begin{array}{l}\text { - Spinted } \\
\text { - Spantaneas } \\
\text { - Cute } \\
\text { - Angreeteasily } \\
\text { - Inconsistent } \\
\text { - Changealde }\end{array}$ & $\begin{array}{l}\text { - Sensitive } \\
\text { - Deailed } \\
\text { - Fussy } \\
\text { - Toosensitive } \\
\text { - Depressed } \\
\text { - Reengful } \\
\text { - Moody }\end{array}$ & $\begin{array}{l}\text { - Adaptable } \\
\text { - Contrdled } \\
\text { - Patient } \\
\text { - Blank } \\
\text { - Slow } \\
\text { - Sluggish }\end{array}$ & $\begin{array}{l}\text { - Resarreful } \\
\text { - Foreful } \\
\text { - Resistant } \\
\text { - Impatient } \\
\text { - Argumetative } \\
\text { - Shat terperate } \\
\text { - Rash }\end{array}$ \\
\hline Attitudes & $\begin{array}{l}\text { - Playful } \\
\text { - Refireding } \\
\text { - Lively } \\
\text { - Messy } \\
\text { - Showzdfs } \\
\text { - Lad } \\
\text { - Restless }\end{array}$ & $\begin{array}{l}\text { - Considaate } \\
\text { - Respettul } \\
\text { - Resertful } \\
\text { - Skeptical } \\
\text { - Alienated }\end{array}$ & $\begin{array}{l}\text { - Satisied } \\
\text { - Indfensive } \\
\text { - Tderant } \\
\text { - Aimless } \\
\text { - Timid } \\
\text { - Mumbles } \\
\text { - Lazy } \\
\text { - Compromising }\end{array}$ & $\begin{array}{l}\text { - Pesuasive } \\
\text { - Positive } \\
\text { - Indqpendant } \\
\text { - Frank } \\
\text { - Stubbom } \\
\text { - Intderant }\end{array}$ \\
\hline Responsibility & $\begin{array}{l}\text { - Optimistic } \\
\text { - Forgetfil } \\
\text { - Wantsceeit } \\
\text { - Disarganized } \\
\text { - Scattedrained }\end{array}$ & $\begin{array}{l}\text { - Sdf sacificing } \\
\text { - Scheduled } \\
\text { - Ordaty } \\
\text { - Faithfiul } \\
\text { - Chart naker } \\
\text { - Bashfil }\end{array}$ & $\begin{array}{l}\text { - Peactul } \\
\text { - Submissive } \\
\text { - Contented } \\
\text { - Indeisive }\end{array}$ & $\begin{array}{l}\text { - Sdf-rdiant } \\
\text { - Daning } \\
\text { - Løder } \\
\text { - Lardorer } \\
\text { - Crafty } \\
\text { - Warkahdic }\end{array}$ \\
\hline Sociability & $\begin{array}{l}\text { - Sociable } \\
\text { - Promater } \\
\text { - Dedightfil } \\
\text { - Inspining } \\
\text { - Repetitions }\end{array}$ & $\begin{array}{l}\text { - Thargitful } \\
\text { - Lgal } \\
\text { - Withdrawn } \\
\text { - Introat } \\
\text { - Laner }\end{array}$ & $\begin{array}{l}\text { - Shy } \\
\text { - Friendly } \\
\text { - Diplomatic } \\
\text { - Listener } \\
\text { - Rductant }\end{array}$ & $\begin{array}{l}\text { - Outspoken } \\
\text { - Bossy } \\
\text { - Tadless } \\
\text { - Dominering }\end{array}$ \\
\hline
\end{tabular}

\section{METHOD}

This study used a qualitative approach using a descriptive exploratory method to reveal the data. The subjects were students of class XI Science SMAN 1 Manyar, G resik, East Java, academic year 2010-2011. Research subjects are taken from regular classes and selected students using personality questionnaires patterns tendency main points adapted from Littaeur (1996). The subject of this study is focused on individual patterns of personality tendencies and has an average equivalent mathematical ability. It was conducted by researchers to avoid the perception that the results of the student's answers on the problem solving test is affected by high, mid, or low each subjects. In this study selected four subjects from the classification of students based on the personality tendencies questionnaires that have been given to represent each pattern personality tendencies.

The next stage, researchers continue collecting data by giving a written test. The written test is 
application form of some issues that have been frequently applied in real life. The test was conducted twice. This is done to notice the validity of the data. In each subject worked on the written test, interviews were conducted at the same time. Interview subjects in this study based on tasking interview. It means that the subjects was given the questions about how and why he took the decision or conduct any subject's activity both cognitively and affectively in solving the problems they face and can be observed by researchers.

Analysis of the data to uncover student's problem solving skills in terms of personality tendencies is done with the following steps:

a. Analyzing the pattern of the subject's personality questionnaire to know the classification of subjects in each category of personality types

b. Analyzing the results of the student's written test to determine the problem solving process

c. Analyzing the results of the student's interview to determine the actions and attitudes of research subject orally when solving problems

d. Completing triangulation method to compare the data (classification of personality tendencies and response of student's written test were fitted the observed data and image recording data) with data from interviews

\section{DISCUSSION}

From the process of research gained that student tended Melancholic personality fulfilled all indicators mathematical problem solving skills (Table3). In general, the problem solving process of each personality tendencies gave almost identical descriptions. However, four subjects with the different personality tendencies have dissimilar motivations in doing problem solving process. Based on interviews, the researchers found that subject Sanguinist use more of feelings in decision making. Friborg, Barlaug, and Martinussen (2005) stated that Sanguinist has a character named feeling way. It means that the Sanguinist has a tendency to make decisions based on his feelings. That tendency not only can be personal strength but can be personal weakness also if the individual is not aware of and understand how to treat it. Here then the teacher provide guidance on optimizing the student's strength related to problem solving process. The Choleric is dominated by his own way which is believed correct in making decisions. Researchers observed that the Choleric always try to solve his problems complete. Friborg, Barlaug, and Martinussen (2005) stated that the Choleric characteristic of such known as my way. The term means that the Choleric is a great deal of self-confidence and rely on his own knowledge and ability, so that any decision should be taken in a manner that he believed it's correct. This kind of action if directed at the right condition would be strength for the Choleric. The teacher need to be given on the Choleric is providing direction the Choleric using his own way to solve a problem related to mathematics or another common area.

The Melancholic oriented to the detail and systematic process. Friborg, Barlaug, and Martinussen (2005) stated that the detailed of the Melancholic as a form of perfectionism. The point is that people with a Melancholic tendency will always use the best way to take any decision. This detailed character can provide usefulness in subject analyzing activities in any case. The thing that needs to be noted is that the details of the problem solving process do not mean all unrelated things included in the process. To optimize the benefits of the subject in this detail aspect, teacher needs to give student's direction to be able to select and decide the points are more important to solve a problem. Phlegmatic subject has an opposite tendency to the Melancholic subject in terms of completing a task. If the Melancholic always puts the best way to do, then the Phlegmatic prefer the easiest way to do. In 
looking for solving problems, researchers observed that the Phlegmatic use more previously way and avoid to use the new way that has never given an example of its use. Friborg, Barlaug, and Martinussen (2005) called it with easy way. It means that the Phlegmatic has a tendency to do the task in a way that is most convenient. It is necessary noticed by teacher in building his knowledge in the classroom or in providing treatment.

Connecting psychology factors with mathematics achievement became the study of modern mathematics education. The study as described by Fuxiaoping and Li Mingzhen (in Pang Kun, Song Naiqing, and Li Mingzhen, 2010), conducted through observation and understanding of aspects of psychology and education, assembly some research, replacing the old theories and methods with the modern theories and methods of psychology and modern pedagogy, then analyzing the correlation between psychological factors and mathematics achievement of students. Pang Kun, Song Naiqing, and Li Mingzhen (2010) stated that psychological factors are important observed for more is personality type. Premuzic, Furnham, D issou and Heaven (2010) declared that the personality tendencies are a significant determinant on students when the students are exposed to give a response and solution to a problem.

According to Ackerman and Heggestad (2007), another thing that makes the non-cognitive factors become important to understand is that:

Personality traits or self-report inventories (of typical performance) have incremental validity in predicting academic success and failure. Given the current interest in non-cognitive variables to improve our understanding of the development of adult intellectual competence and maximize the prediction of future achievement, understanding the relationship between established personality traits and academic performance outcomes is of fundamental importance.

From the stated above, can be interpreted that understanding the differences personality tendencies of students, including non-cognitive variable, is not only important as an effort to improve the teacher's knowledge in the development of learners psychological aspect, but rather as an alternative way to develop the students potentiality in terms of academic by optimizing the students personality tendencies. Association between of psychological factors and students achievement, including mathematics, is a new analysis that can be considered both in preparing learning and in giving treatment.

Associated with the student's academic achievement, Schoenfeld (in the National Research Council, 2005) pointed that the mission of mathematics education today is not only to improve the academic achievement of students, but also to build and implement instructional practice that involve in student's potentiality both physically and psychologically, so that problem solving skills can be optimally and proportionally developed in accordance with the characteristics of students. 
Table3 The Recapitulation Result of Student's Problem Solving Indicators related to Personality Tendencies

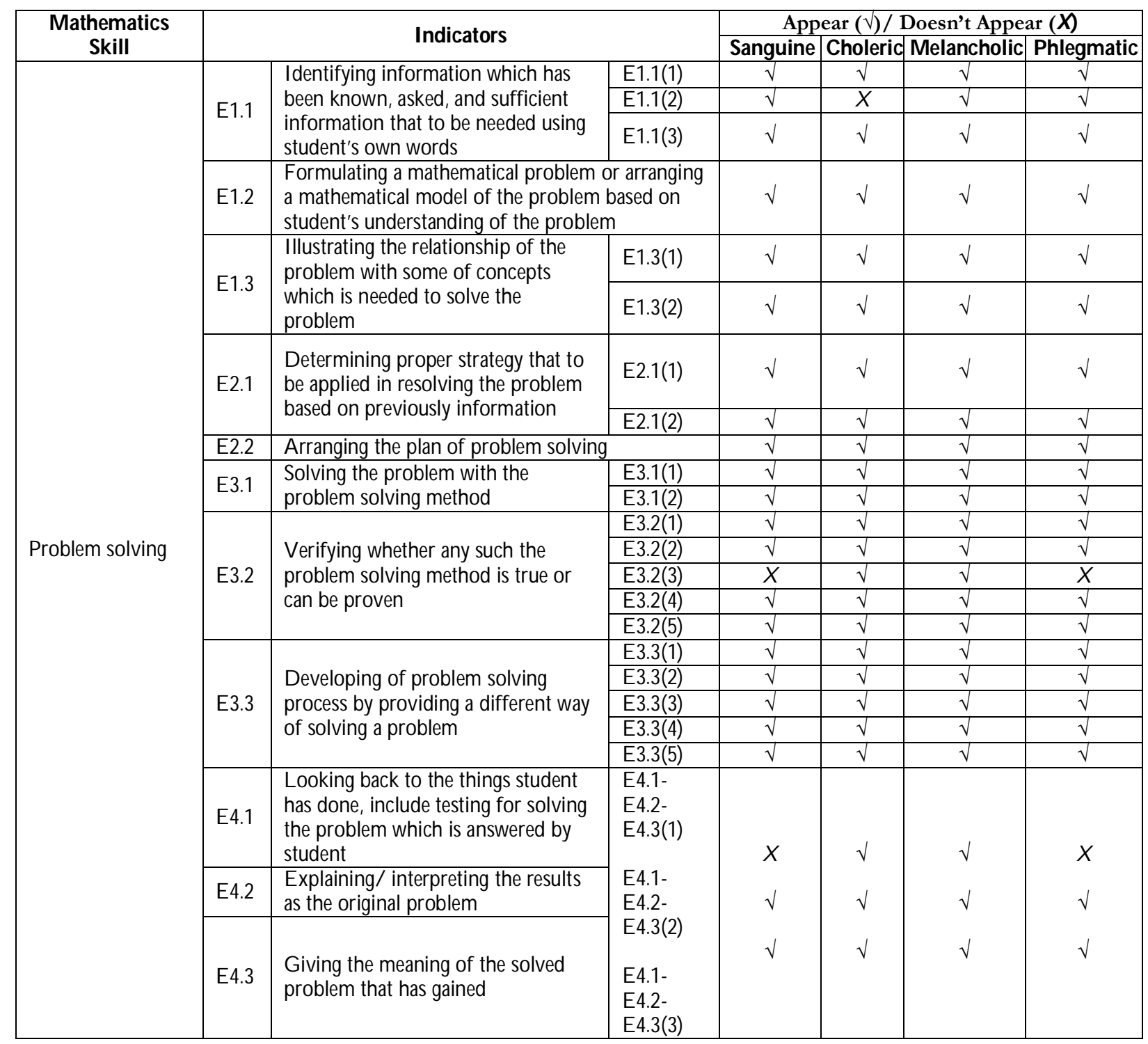

\section{CONCLUSION}

Conclusions of this study are:

a. The Melancholic tendency fulfilled all indicators mathematical problem solving skills

b. In doing problem solving process the Sanguinist use more of feelings in decision making. It characteristic is named fedingway. The Choleric is dominated by his own way which is believed correct in making decisions. It characteristic of such known as my way. The Melancholic oriented to the detail and systematic process. The point is that people with a Melancholic tendency will always use the best wayto take any decision. The Phlegmatic use more previously way and avoid to use the new way that has never given an example of its use. It characteristic called as @sy way.

c. Each personality tendencies showed the solving problem process in the different way. For that the teachers should to know and detect the students' personality tendencies, not just to know the advantages and disadvantages of each tendency, but rather to attempt how to optimize the student's potentiality. The description of the response of each personality tendency in the problem solving process can assist the teacher to notice the students strength in order give the opportunity to the student develop his achievement. 


\section{REFERENCES}

Anderson, Judy. 2009. Mathematics CuriaulumDexdqumet and the Rdeof ProdemSdving Sydney: The University of Sydney. Retrieved from: http:// www.acsa.edu.au/pages/ images/ Judy\%20Anderson\%20-\%20Mathematics\%20Curriculum\%20D evelopment.pdf [D ownloaded April 10 $\left.0^{\text {th }}, 2014\right]$.

Chapman, Alan. 2009. Pesconlity Theries, Types and Tests Retrieved from: http:/ / www.e-stimate.dk/ nyheder/ teorierne_bag.pdf [D ownloaded March 15 $5^{\text {th }}, 2011$ ].

Friborg O., Barlaug D., Martinussen M. 2005. Resiliemein Rdation to Pescomality and Intelligence International Journal of Methods in Psychiatric Research, 2005, Volume 14, Number 1, pages 29-42.

Giganti, Paul. 2007. Why Tead ProddemSdving Part I: TheWold Needs GoodProddemSdves! California: Berkeley Edu.

Latterell, Carmen M. 2007. Todays Mathematics Students D uluth: University of Minnesota.

Littauer. 1996. PesconalityPlus Jakarta: Bina Aksara.

NCTM. 2000. Piniples and Standards for Schod Mathematics Retrieved from: http:/ / www.nctm.org/ standards/ content.aspx?id=26862 [D owloaded February 17 , 2011].

NRC. 2005. A Visionof Mathematical PowerandA preiationforAll Retrieved from: http:/ / www.sde.ct.gov/ sde/ lib/ sde/ PD F/ Curriculum/ Curriculum_Root_Web_Folder/ mathgd_chpt1.pdf [D ownloaded D ecember 28 $\left.8^{\text {th }}, 2010\right]$.

O ktaviyanthi, Rina. 2007. HubunganPda Kepribadian danDominas Heniser TehadapKemampuanMenbaca Matenatika Siswa Thesis on D epartment of Mathematics Education, UPI: limited published.

PCS (Pinellas County Schools). 2005. Mathematical Poner ForAll StudantsK-12 Retrieved from : http:/ / fcit.usf.edu/ fcat8m/ resource/ mathpowr/ fullpower.pdf [D owloaded D ecember 28 $8^{\text {th }}$, 2010].

Uno, Hamzah B. 2007. Modd Penbdajaran Meniptakan Proses Bdajar Mengajar YangKreatif dan Efektif Jakarta: PT. Bumi Aksara. 